\section{Landslides and liquefaction triggered by the M 7.9 Denali Fault earthquake of 3 November 2002}

Edwin L. Harp and Randall W. Jibson, U.S. Geological Survey, 1711 Illinois Street, Golden, Colorado 80401, USA

Robert E. Kayen and David K. Keefer, U.S. Geological Survey, 345 Middlefield Road, Menlo Park, California 94025, USA

Brian L. Sherrod, U.S. Geological Survey, Department of Earth and Space Sciences, University of Washington, Seattle, Washington 98195, USA

Gary A. Carver, 12021 Middle Bay Drive, Kodiak, Alaska 99615, USA

Brian D. Collins, Robb E.S. Moss, and Nicolas Sitar, Department of Civil and Environmental Engineering, 440 Davis Hall, University of California, Berkeley, California 94720, USA sible explanation for the unusual ground-failure patterns that are related to three subevents that have been discerned from the earthquake records.

\section{INTRODUCTION}

South-central Alaska and the Alaska Range were severely shaken on the morning of 3 November 2003 by a (moment magnitude) $\mathbf{M} 7.9$ earthquake. ${ }^{1}$ The quake triggered more than $300 \mathrm{~km}$ of surface rupture along the Denali Fault and numerous landslides and liquefaction failures within the central part of the Alaska Range and surrounding areas (Eberhart-Phillips et al., 2003). Landslides triggered by the earthquake were mainly rock falls and rock slides containing different amounts of ice and snow. The most spectacular landslides triggered by the shaking were large rock and ice avalanches that occurred on the Black Rapids Glacier, the Gakona Glacier, the West Fork Glacier, and the McGinnis Glacier. These landslides ranged in volume from several hundred thousand cubic meters to 40 million cubic meters. Widespread liquefaction occurred within alluvial deposits of rivers and streams in and adjacent to the central Alaska Range and within artificial fills in the same area. Surface manifestations of liquefaction were mainly lateral-spreading cracks and sand boils. Subsidence effects also were observed in structures at Fielding Lake and along the Alaska Pipeline. Only one strong-motion seismometer was present within the near field. Patterns of triggered landslides and liquefaction effects taken together with teleseismic data provide most of the evidence of the variation of strong shaking.

\section{PATTERN OF FAULT RUPTURE}

The November 3 earthquake, one of the largest in U.S. history, resulted primarily from right-lateral movement on the Denali-Totschunda Fault system (Fig. 1). The Denali Fault is one of the longest strike-slip fault systems in the world; it consists of numerous strands along its $2000 \mathrm{~km}$ length and is comparable in size to the San Andreas Fault, which produced the M 7.8 San Francisco earthquake of 1906 (Miller et al., 2002). The Totschunda Fault, a major splay of the Denali Fault system, extends $\sim 200 \mathrm{~km}$ from the U.S.-Canada border northwest to its junction with the Denali Fault at Mentasta Pass (Plafker et al., 1994; Plafker et al., 1977). The Denali and Totschunda Faults both display evidence of recent movement.

The $\mathbf{M} 7.9$ mainshock was preceded by a $\mathbf{M} 6.7$ foreshock on 23 October 2002 (Fig. 1) on the Denali Fault. The epicenter of the mainshock was $\sim 25 \mathrm{~km}$ east of the foreshock. The mainshock consisted of multiple subevents (Kikuchi and Yamanaka, 2002). The first subevent was a $\mathbf{M} 7.2$ thrust event near the Susitna Glacier. This event then triggered a second subevent (Fig. 1), a right-lateral rupture on the Denali Fault near the West Forks Glacier. During a third subevent (Fig. 1), right-lateral rupture propagated eastward along the Denali Fault for 225 $\mathrm{km}$ (Frankel et al., 2002) and continued for $\sim 50 \mathrm{~km}$ southeastward on the Totshunda Fault. Right-lateral slip averaged $\sim 3.5 \mathrm{~m}$ and ranged from 0.5 to almost $9 \mathrm{~m}$. A maximum of $\sim 3.5 \mathrm{~m}$ of vertical movement occurred as both thrust and normal slip. Old degraded fault scarps (Plafker et al., 1977) observed at many places were re-ruptured during the November 3 event.

The fault ruptured across the route of the Trans-Alaska pipeline (TAPS). The

${ }^{1}$ Boldface " $\mathrm{M}$ " indicates moment magnitude. Standard "M" used when the type of magnitude is not specified. 


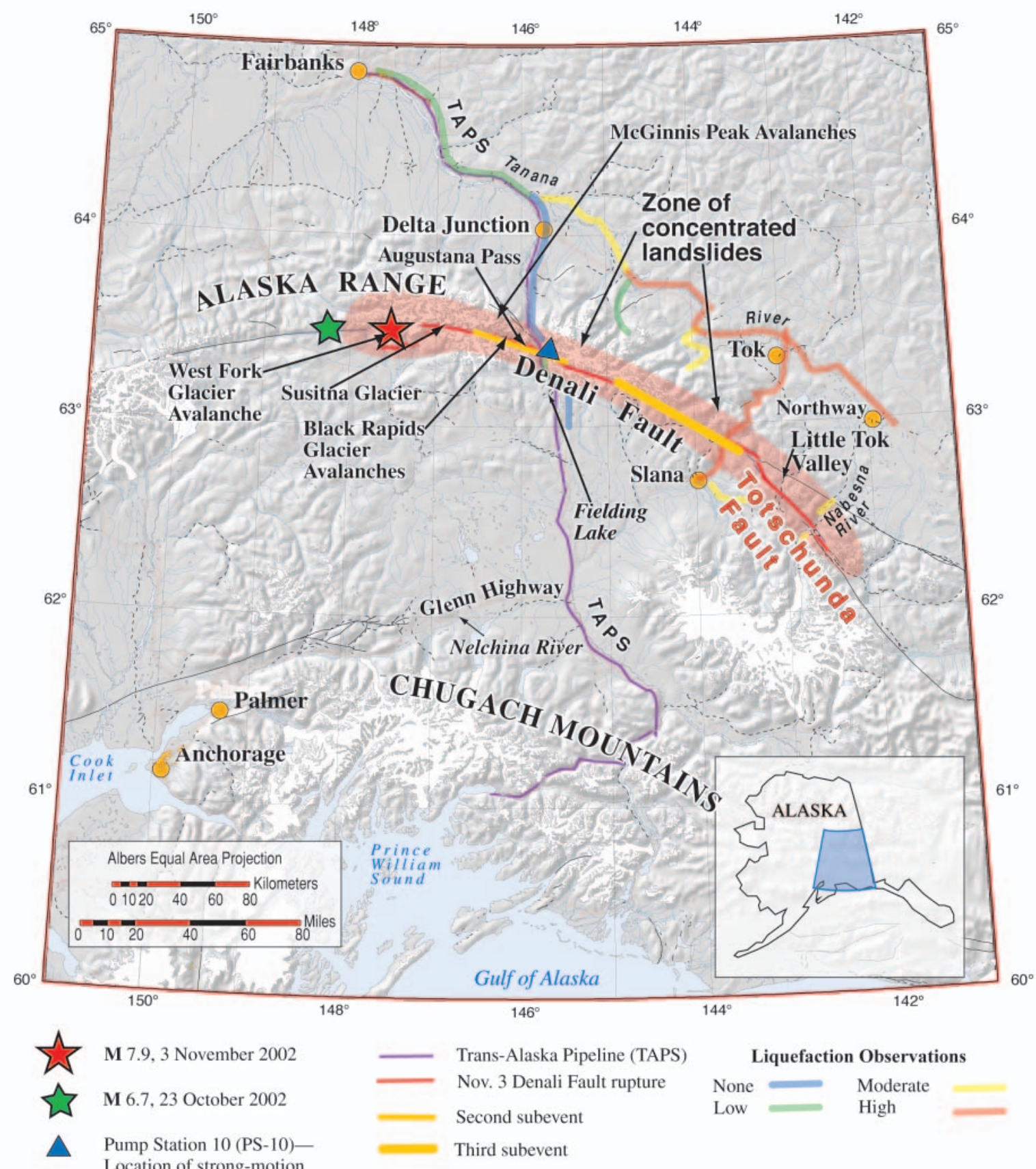

Location of strong-motion seismograph that recorded the Denali Fault earthquake

Figure 1. Map showing mainshock, foreshock, zone of fault rupture, concentrated landslides, individual landslides and places mentioned in text, and observations of liquefaction effects triggered by the Denali Fault earthquake of 3 November 2002.

pipeline's earthquake monitoring system and pipeline personnel initiated an automatic shut-down after the earthquake. Supports for the pipeline were damaged, causing the pipeline to sag in a few places, but the pipeline did not break and alarm systems worked as designed. Some minor subsidence of the pipeline occurred due to liquefaction within artificial fill $\sim 500 \mathrm{~m}$ south of the fault rupture. The pipeline was designed and built to withstand the effects of a M 8.0 earthquake generating as much as $8 \mathrm{~m}$ of slip.

\section{LANDSLIDES TRIGGERED BY THE EARTHQUAKE}

The violent, prolonged shaking from the Denali Fault earthquake triggered thousands of landslides from the steep slopes of the Alaska Range and surrounding areas. The distribution of landslides was determined by reconnaissance from both fixed-wing aircraft and helicopter. The landslides ranged in size from a few cubic meters of dislodged rock to large rock avalanches of 5-40 million cubic meters triggered from steep rock cliffs bordering large valley glaciers Avalanche deposits of rock and ice blanketed large sections of the Black Rapids and McGinnis Glaciers.

An unusual aspect of the landslides triggered by this earthquake was their narrow concentration along the fault rupture. Normally, an earthquake of this magnitude would be expected to trigger abundant landslides over a very broad region extending perhaps $350 \mathrm{~km}$ from the fault and covering an area of 25,000 to perhaps 75,000 km² (Keefer, 1984, 


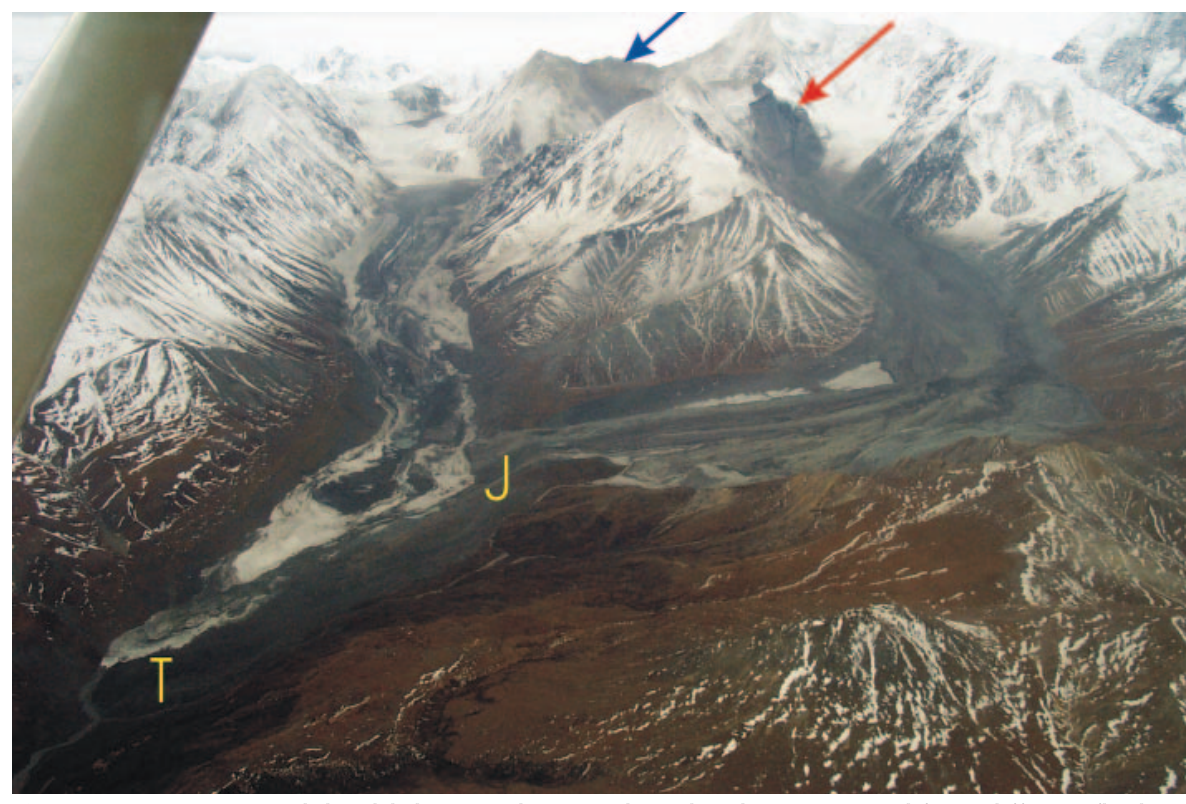

Figure 2. McGinnis Peak landslides. Two huge rock avalanches originated from different flanks of McGinnis Peak. The avalanche to the right (red arrow denoting head scarp) is composed mainly of rock and is $\sim 40$ million $\mathrm{m}^{3}$ in volume. The runout path of this avalanche is $\sim 10 \mathrm{~km}$. The avalanche to the left (blue arrow denoting head scarp) has more ice and snow included within the avalanche debris. The landslides converged in the lower left part of the photo (J), and the avalanche on the left continued down to the toe of McGinnis Glacier (T).
Palmer, Alaska, $250 \mathrm{~km}$ southwest of the fault. The pattern of landslides suggests that shaking levels necessary to trigger abundant rock falls and rock slides were focused in a narrow band centered along the fault zone rather than extending radially outward for great distances. With few seismic instruments in this region, the pattern of landsliding may be one of the best indicators of the pattern of ground shaking.

By far the most impressive landslides were large rock avalanches that spilled onto glaciers in the Alaska Range. These were reminiscent of avalanches triggered by the $1964 \mathbf{M} 9.2$ Alaska earthquake in the Chugach Range (Tuthill and Laird, 1966). All of the 2002 avalanches were located along the fault rupture between the first and second subevents. The largest of these, the McGinnis Peak landslide (scar shown by arrow in Fig. 2), involved $\sim 40$ million $\mathrm{m}^{3}$ of metamorphic rock and 10\% glacial ice that collapsed from a southeast ridge of McGinnis Peak, struck the glacier below the rock face, and then flowed $10 \mathrm{~km}$ down the
2002). In this earthquake, the majority of landslides clustered in a narrow band $\sim 30 \mathrm{~km}$ wide that straddles the fault for more than $300 \mathrm{~km}$ (Fig. 1). Only a few rock falls were found at greater distances from the fault, despite the fact that highly susceptible, steep slopes of intensely fractured rock are abundantly present beyond the observed $15 \mathrm{~km}$ limit on each side of the fault. The most distant triggered landslides we observed were a few scattered rock falls in the Chugach Mountains near glacier (Fig. 2). About $7 \mathrm{~km}$ into its travel path, the avalanche debris followed a turn of $\sim 70^{\circ}$ in the glacier valley and ran up on the valley walls on the outside of the turn 60-80 m, indicating a high velocity of movement. Snow 50-70 $\mathrm{m}$ high on valley walls was covered with dust, suggesting that the landslide generated a thick dust plume in front of it. Avalanches triggered by other earthquakes have moved at speeds of up to $250-300 \mathrm{~km}$ per hour (Plafker et al., 1971). The toe of the McGinnis Peak
Figure 3. Rock avalanches deposited on the surface of the West Fork Glacier near the earthquake epicenter. "S" indicates source areas within the cirques where recent snow obscures their features. " $\mathrm{R}$ " indicates runout paths of the avalanche deposits.

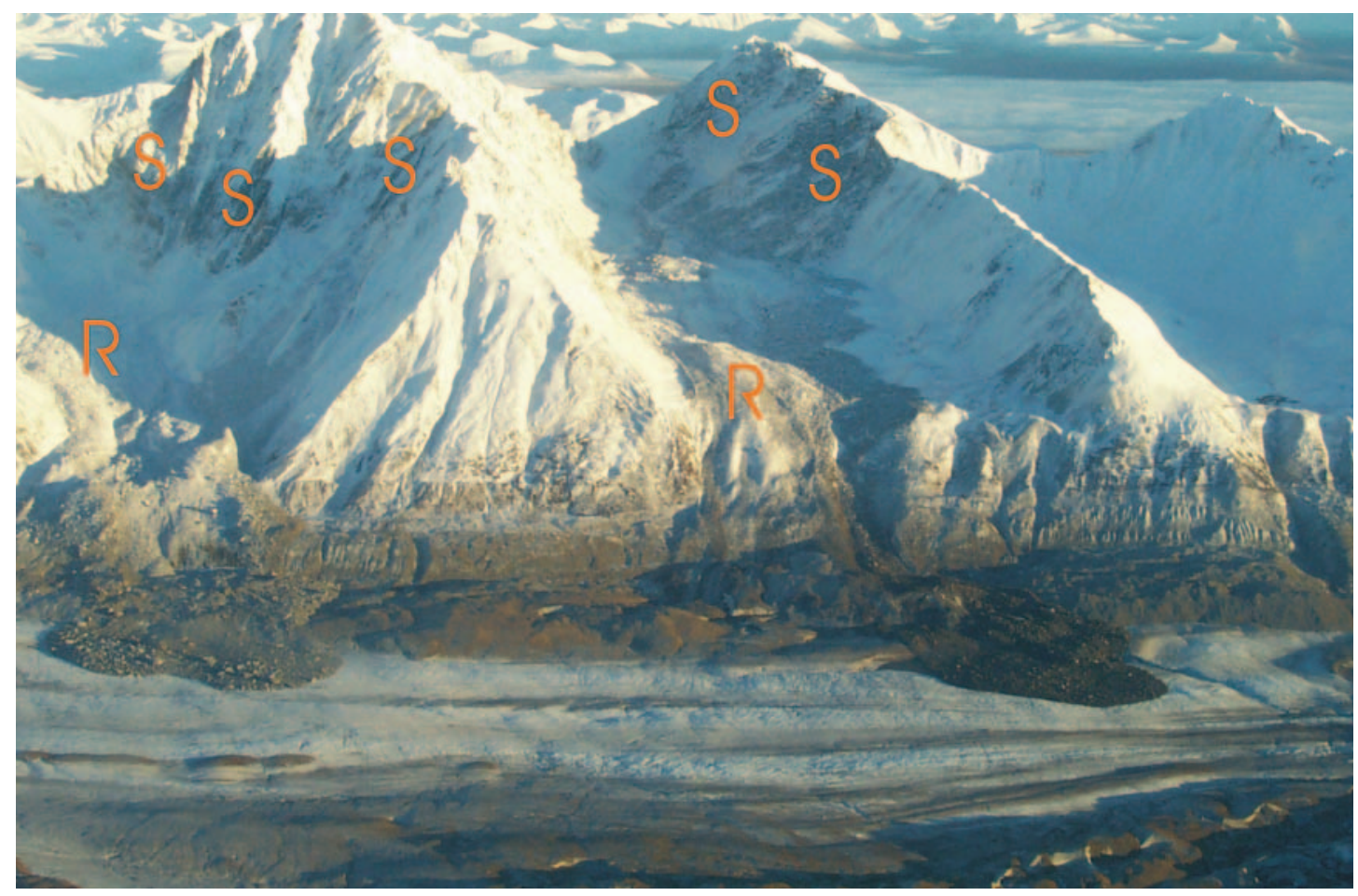

AUGUST 2003, GSA TODAY 


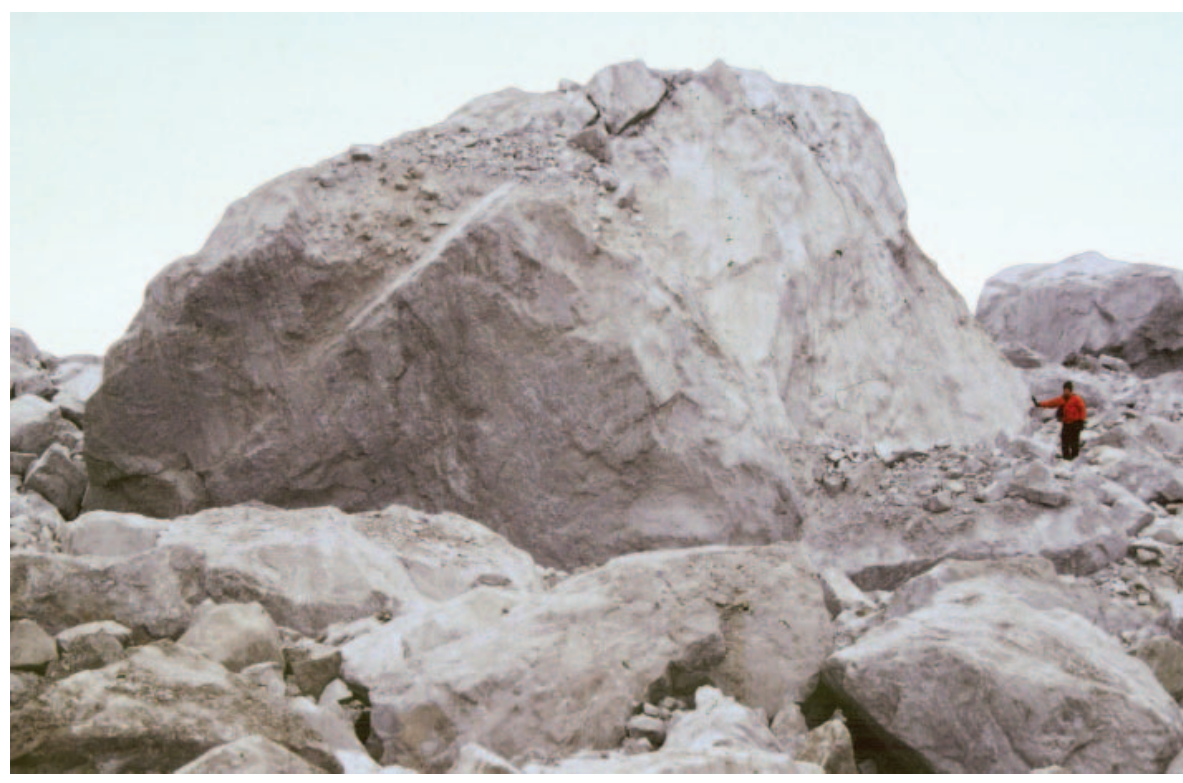

Figure 4. Deposit of one of the West Fork Glacier avalanches consisting primarily of huge blocks. The block shown (with a person for scale) is $20 \mathrm{~m}$ in longest dimension.

rock avalanche eventually butted up against another similar rock and ice avalanche that was triggered from the southern ridge of the peak. The toe of this avalanche traveled another kilometer past this junction almost to the toe of McGinnis Glacier. This avalanche contained significantly more ice and snow, perhaps as much as $30 \%$ of the volume of the deposit.

When we compared the runout distance of the McGinnis Peak rock avalanche with those of other avalanches worldwide, using data from Shaller (1991) and Evans and Clague (1988), we find that the McGinnis Peak rock avalanche plots within the data cluster of landslides similar in volume, indicating that its runout distance is not exceptional despite the entire runout path being on ice.

Several other large rock avalanches were triggered from granite slopes along the south margin of the Black Rapids Glacier. The three largest of these landslides each had volumes of several million cubic meters. They cascaded down steep rock slopes, crossed a lateral moraine at the valley's margin, and then spread out $\sim 2.5 \mathrm{~km}$ across the glacierfilled valley, coming to rest against the opposite valley wall. The deposits were uniformly thin, $2-3 \mathrm{~m}$ in most areas, including where the avalanche debris spread up and over a $15 \mathrm{~m}$ high medial moraine. The earthquake opened deep fissures adjacent to some of the landslide source areas above Black Rapids Glacier. These fractures delineate incipient landslides even larger than those triggered in the November 3 earthquake that may reactivate in future earthquakes, heavy rainfall, or snowmelt episodes.

Two large rock avalanches were triggered above the West Fork Glacier (Fig. 3) from near-vertical slopes in two glacial cirques, shown in Figure 3. As the dislodged rock moved rapidly down the cirques, debris from the avalanche to the left in Figure 3 became airborne for a short distance as it traveled over the lateral moraine at the edge of the valley and spread out as it fell onto the glacial surface. Parts of the lee side of this lateral moraine were undisturbed by the avalanche, indicating that at least some of the avalanche debris must have been airborne to avoid impact with this part of the moraine. The deposit of this avalanche mainly consisted of large blocks of metamorphic rock (possibly as much as $70 \%$ by volume); some individual blocks were more than $20 \mathrm{~m}$ on a side (Fig. 4). Thicknesses of the deposits ranged between 3 and $15 \mathrm{~m}$.

\section{LIQUEFACTION OF HOLOCENE RIVER DEPOSITS}

Liquefaction-induced ground failures were widespread throughout east-central Alaska to distances well beyond the 15 $\mathrm{km}$ limit from the rupture that is shown by most other landslides. Liquefaction is a phenomenon that occurs in a buried layer of unconsolidated, water-saturated, generally small to medium sand-sized sediment during prolonged shaking in an earthquake. In liquefaction, the sedimentary particles in the buried layer reorient themselves to occupy less space and force water out of pore spaces. Overlying layers that are unsaturated or more consolidated (or frozen) find themselves rafted on a layer of liquefied soil that has little or no shear strength and become destabilized, moving downhill (lateral spreading) and fracturing to allow the water to escape in sand boils. Liquefaction from the Denali Fault earthquake induced debris flows, lateralspreading failures, and sand boils.

The distribution of liquefaction effects depended upon the location of susceptible deposits, which were mainly alluvial deposits along the rivers in the area and also included lake-margin sediments and artificial fill. Reconnaissance by air and by driving parts of the sparse surface road network suggested that liquefaction effects extended out from the surface rupture for $\sim 100-120 \mathrm{~km}$; however, this limit is not well determined. In addition to liquefaction features, soil slides and flows were observed within fine-grained deposits along the banks of the Nelchina River south of the Glenn Highway, 200 $\mathrm{km}$ from the zone of fault rupture.

Liquefaction effects increased notably in severity and spatial extent toward the east end of the rupture zone (Fig. 1). On the north side of the Alaska Range in the Tanana River valley (Fig. 1), at 50-120 $\mathrm{km}$ from the zone of fault rupture, we saw extensive evidence of liquefaction where fluvial deposits of sand and silt were capped by a thin $(<0.3 \mathrm{~m})$ frozen surface layer. Liquefaction within the Tanana River valley was widespread from Fairbanks on the west to at least several hundred kilometers eastward. Liquefaction damage became increasingly severe to the east of Delta Junction, even as distance from the fault increased. In the Tok area, nearly every river bar contained extensive liquefaction effects. Farther east, for many kilometers around the towns of Northway and Slana, large continuous lowland areas of liquefaction and lateral-spread failures were observed. Two measured transects along the Tanana River at Tetlin Bridge, west of Tok, showed 3\%-4\% of lateral spreading of sand bars across 


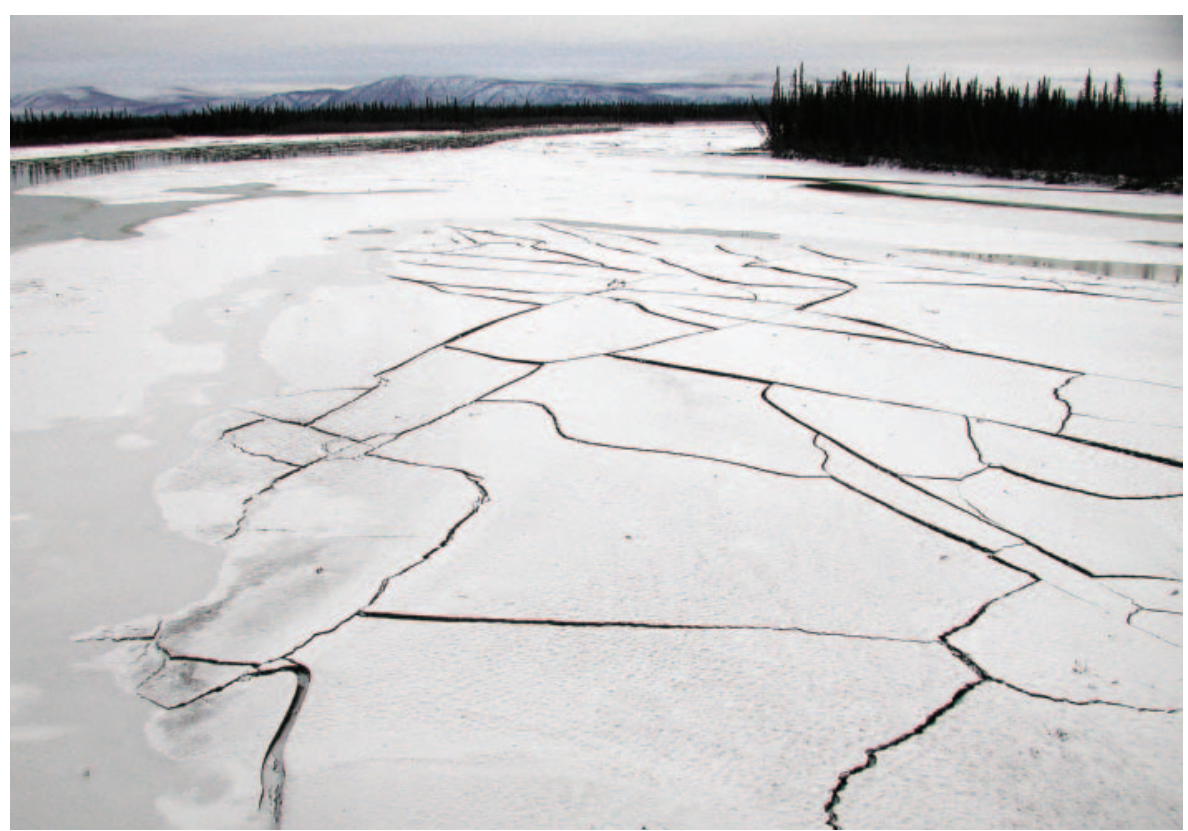

Figure 5. Polygonal cracks in frozen surface of floodplain deposits of Tanana River. For several hundred kilometers along the Tanana River (here near the town of Tetlin Junction), a pattern of polygonal surface fractures defined liquefaction-induced laterally deforming ground. The polygons formed when the frozen crust $(\leq 0.3 \mathrm{~m}$ thick) above liquefied ground fractured and displaced.

distances of $200 \mathrm{~m}$ (21 fissures) and 400 $\mathrm{m}$ (48 fissures). In some places separate lateral spreads collided and their frozen crusts buckled and thrust over one another, resulting in contraction of as much as $4.5 \mathrm{~m}$. Parallel fissures formed locally where the ground spread laterally toward the river. More commonly, the frozen ground surface displayed randomly oriented sublinear fissures, which formed polygon networks that could be traced for several kilometers (Fig. 5).
In the Northway area, a region of lowlands with swamps, liquefaction-related ground failures were ubiquitous. The Northway area is $130-180 \mathrm{~km}$ from the section of maximum displacement on the Denali Fault and $\sim 80 \mathrm{~km}$ from the closest point on the Totschunda Fault rupture. Lateral spreading rendered the airport at Northway unusable. The frozen surface layer and paved runway at Northway were cut by fissures, many $10-30 \mathrm{~cm}$ wide with some $1 \mathrm{~m}$ wide or greater, spaced meters to tens of meters apart. Fractures as wide as $1 \mathrm{~m}$ and as long as $10 \mathrm{~m}$ opened along the perimeter of the runway and vented silt, coarse to fine sand, and pebbles. Associated with the sand boils were sinkholes as much as $4 \mathrm{~m}$ in diameter and $1 \mathrm{~m}$ deep. Anecdotal reports from residents describe water and soil spewing 2-4 $\mathrm{m}$ into the air. Parallel and polygonal patterns of lateral spreads similar to those observed in the Tanana River bars were observed at Northway, both in the paved runways and in the surrounding undeveloped areas. Away from the runway, houses and structures were unseated and tilted on their foundations, and road settlement bent and crushed drainage culverts.

The flood plain of the Nabesna River, $10-15 \mathrm{~km}$ from the eastern end of the

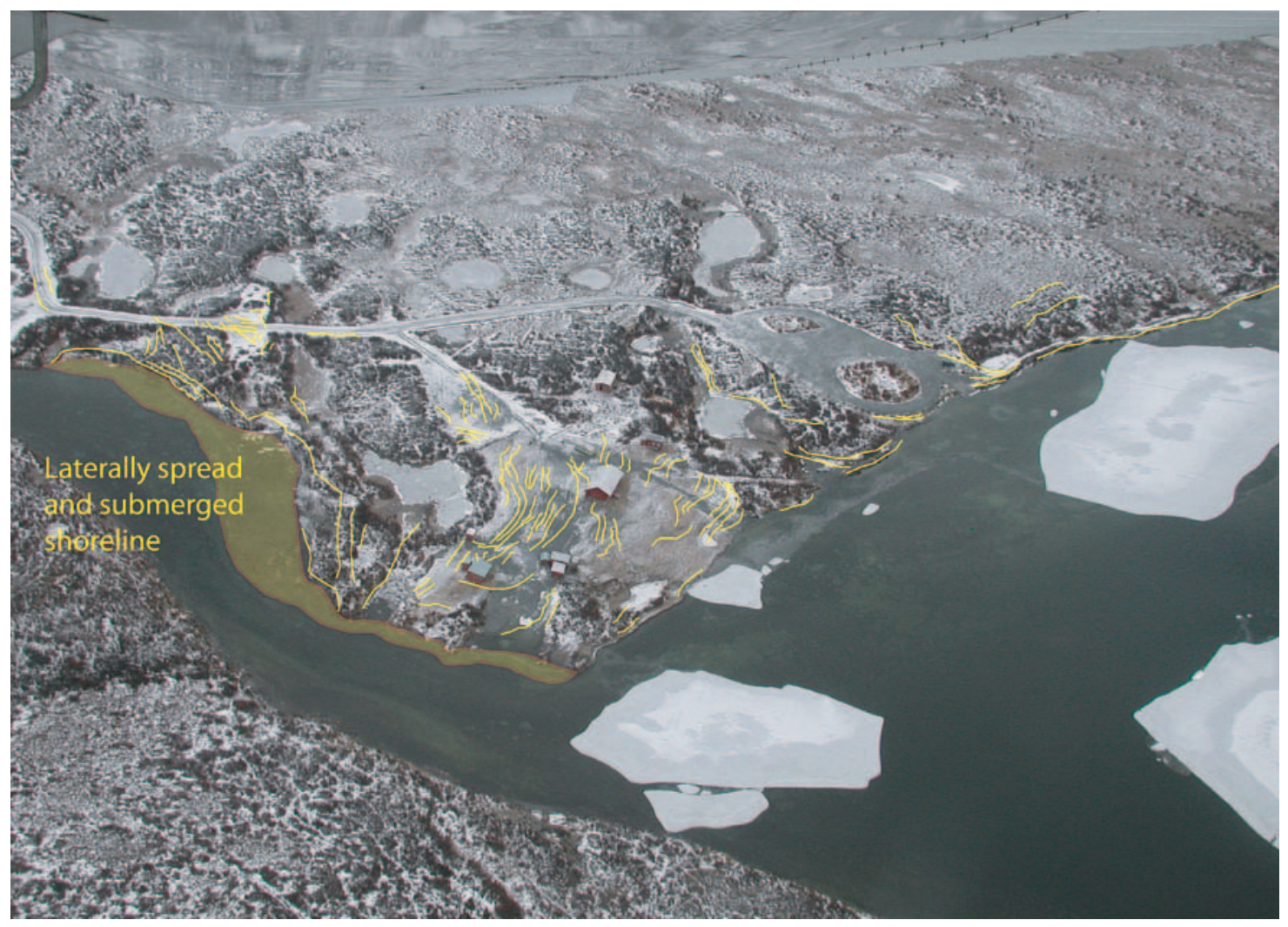

Figure 6. Lateral spreads and sand vents above liquefied ground at Fielding Lake Park was observed from the air and later mapped. The pattern of fissures (yellow lines) are generally across slope as ground slid toward low land areas and the lakeshore. 
Totschunda Fault rupture, was cut by numerous fissures, most with sand boils. In contrast to the finer-grained sediment (silty sand) in the Tanana River and Northway regions, the liquefaction at the Nabesna River valley was in gravelly sand.

Widespread liquefaction, lateral spreading, sand boils, and submerged ground were observed at Fielding Lake, where the upper soil crust was not frozen at the time of the earthquake (Fig. 6). Structures on the spreading ground were deformed and displaced, including an underground septic tank that was buoyed to the surface, lifting an outhouse.

Approximately $11 \mathrm{~km}$ north of Fielding Lake and $\sim 500 \mathrm{~m}$ south of the fault rupture, minor damage was done to the Alaska pipeline where the pipeline and a regulator valve sank $75 \mathrm{~cm}$ into artificial fill that liquefied during the shaking. About $300 \mathrm{~m}$ south of this point, there were isolated sand boils and lateral-spreading cracks in the alluvium of the Delta River.

Concentrations and severity of liquefaction effects were especially high over a large region near the eastern end of the ruptured Denali Fault and the Totschunda Fault, where the fault displacement was greatest (Fig. 1).

In addition to liquefaction, cracking of ice on lakes is another measure of ground shaking. A number of lakes dot the region, many of which were partially frozen at the time of the earthquake. Cracking of lake ice due to ground shaking was prevalent over the entire region. Cracked lake ice was observed within $30-40 \mathrm{~km}$ of the fault along the western part of the rupture, whereas to the east, lake-ice cracking extended $\sim 100 \mathrm{~km}$ away from the fault. This eastward increase resembles the regional pattern of liquefaction.

\section{COMPARISON OF LANDSLIDE AND LIQUEFACTION DISTRIBUTION WITH STRONG-MOTION CHARAC- TERISTICS OF THE EARTHQUAKE}

Both landslides and liquefaction effects from the Denali Fault earthquake occur within the 30-km-wide zone that parallels the fault rupture, but liquefaction effects also extend significantly outside this zone, a relationship that is unusual for ground-failure distributions in earthquakes. Keefer's (1984) data from
40 worldwide earthquakes show that the distance limits from both epicenter and fault-rupture zone for landslides and liquefaction-induced failures are close to each other at earthquake magnitudes of 7.5-8.5, but that landslide limits are still greater than limits of liquefaction.

Further, the concentration of the large rock avalanches near the first two subevents is also in contrast with the broad eastward distribution and concentration of liquefaction effects in the area of the third subevent of the earthquake. In the eastern part of the area, liquefaction effects were much more extensive and deformation more severe than in areas to the west near the first and second subevents. Because the earthquake was recorded by only one strong-motion instrument in the near field (Pump Station \#10 near the fault rupture along the Richardson Highway, PS-10), it is impossible to completely resolve these apparent inconsistencies in the two distributions of ground failure. However, preliminary analysis of teleseismic data has allowed some insight into the problem and some tentative explanations.

\section{Landslide Distribution}

The narrow concentration of rock falls, rock slides, and large rock avalanches along the fault-rupture zone suggests that the highest accelerations generated from this earthquake did not extend far from the fault zone. Failures in brittle rock are sensitive to high accelerations commonly within the higher frequencies of ground motion. Relative to other earthquakes of comparable or lower magnitudes (1987 Ecuador M 6.9; 1970 New Guinea M 7.1; 1976 Darien, Panama M 7.0; 1977 San Juan, Argentina M 7.4; 1970 Peru M 7.9) for which landslide concentrations have been measured or estimated (Keefer, 1993) the Denali earthquake had significantly lower concentrations of rock falls and rock slides. Lower concentrations of rock falls and rock slides suggest that the earthquake shaking was deficient in high-frequency energy and high peak accelerations. The maximum recorded acceleration (which is still being confirmed; C. Stephens, 2003, personal commun.) of $0.34-0.40 \mathrm{~g}$ (PS-10) $3 \mathrm{~km}$ north of the fault rupture along the Richardson Highway is a fairly modest peak acceleration for an earthquake of this magnitude. During the 1994 Northridge, California, earthquake (M 6.7), accelerations exceeded $1.0 \mathrm{~g}$ and triggered more than 11,000 landslides with concentrations of hundreds of slides per square kilometer (Harp and Jibson, 1995).

Because the first subevent of the Denali Fault earthquake was a $\mathbf{M} 7.2$ thrust in the epicentral area, we would have expected to see similar landslide concentrations there as we saw from the Northridge earthquake. Although large rock avalanches were triggered in this area, we were surprised that the overall concentrations of landslides were significantly lower than those triggered by the Northridge earthquake.

Keefer's (2002) relationship between areas affected by landslides and earthquake magnitude shows that the mean area affected by a $\mathbf{M} 7.9$ earthquake is $\sim 28,000 \mathrm{~km}^{2}$. Based on the landslide distribution shown in Figure 1, the area affected by the November 3 earthquake measures only $10,000 \mathrm{~km}^{2}$. In contrast, the area affected by landslides triggered by the 1964 Alaska earthquake of $\mathbf{M} 9.2$ was $\sim 200,000 \mathrm{~km}^{2}$, and the farthest landslides were triggered $700 \mathrm{~km}$ from the epicenter (Keefer, 1984, 2002).

Few landslides were triggered west of the epicenter; most of the landslides, including the large rock avalanches, were located east of the epicenter. This pattern is clearly consistent with the propagation of the second and third subevents of the earthquake, which were directed to the east (A. Frankel, 2003, personal commun.). To the west of the epicenter, areas of concentrated rock falls and rock slides disappear within $30 \mathrm{~km}$ of the epicenter, whereas to the southeast, the zone of concentrated rock falls and rock slides extends more than $300 \mathrm{~km}$.

All of the largest landslides clustered near the first two subevents, suggesting that this was the area of strongest shaking. These two subevents contained the largest accelerations of the earthquake record (Frankel et al., 2002). The $\mathbf{M} 7.2$ thrust that formed the first subevent may have played a major role in the triggering of large rock avalanches, because thrust events generally have higher-frequency ground motion and higher accelerations than strike-slip events of similar magnitudes. Farther to the east, the absence of large avalanches of rock or snow near where the third subevent 
began suggests that shaking levels were too low.

\section{Distribution of Liquefaction Effects}

The increase in liquefaction effects to the east stands in contrast to the pattern of landslides. We attribute this contrast to the fact that landslides and liquefaction effects are sensitive to different groundshaking parameters. Failures in brittle rock are sensitive to high accelerations commonly within the higher frequencies of ground motion. Small rock failures can be created with extremely short durations of high accelerations.

Liquefaction-induced failure of saturated sediments is often more responsive to shaking duration than to short pulses of high acceleration. The liquefaction process is highly sensitive to repetitive cycles of shear strain (Seed and Lee, 1966). To liquefy, saturated sand, silt, or gravel requires multiple cycles of shear strain to move the grains with respect to each other so that densification can occur and pressurize the interstitial water. Thus, it is not surprising that the effects of liquefaction are more severe and concentrated in areas near the third subevent, because the rupture from this subevent is much longer than that of the second subevent ( $48 \mathrm{~km}$ vs. $27 \mathrm{~km}$ ), and the rupture took longer, giving an expected longer duration for shaking than either the first or second subevents (A. Frankel, 2003, personal commun.).

\section{SUMMARY OF LANDSLIDE AND LIQUEFACTION DISTRIBUTION}

The distributions of landslide and liquefaction effects triggered by the Denali Fault earthquake of 3 November 2002 were unusual in many aspects. Preliminary analysis of the strong-motion characteristics of the earthquake suggest that the distribution of landslides is consistent with the patterns of strong shaking. Duration of shaking, rather than acceleration levels, may have largely determined the distribution and severity of liquefaction effects.

Only one strong-motion instrument (PS-10) was present to record shaking in the near field, so these distributions may provide useful insights into the spatial variations of shaking. Several preliminary conclusions can be drawn from the distribution of landslides and liquefaction effects.
- The accelerations generated by the earthquake were only moderate in amplitude for a magnitude 7.9 event. The maximum recorded acceleration was $0.33-0.40 \mathrm{~g}$

- Acceleration levels high enough to trigger concentrated rock falls and rock slides extended relatively short distances, $\sim 15 \mathrm{~km}$, from the zone of fault rupture.

- The lack of extreme concentrations of rock falls and rock slides within the epicentral area and the near field of the earthquake suggest that high frequencies and attendant high accelerations were missing from this earthquake.

- The clustering of large rock avalanches within the area of the first two subevents of the earthquake is consistent with these subevents containing the highest accelerations of the earthquake record. No large avalanches were present in the area of the third subevent, which generated high displacements associated with it but relatively lower accelerations (Frankel et al., 2002).

- Landslides extended only short distances to the west of the epicentral area of the earthquake, whereas to the east, they extended for over 300 $\mathrm{km}$ along the zone of fault rupture, presumably because of the eastward extension of shaking that attended the eastward propagation of fault rupture.

- Liquefaction features were observed well beyond the zone of concentrated landslides, an unusual situation suggesting that minimum shaking levels and duration requirements for liquefaction extended well beyond the zone of acceleration levels high enough to trigger rock falls and rock slides.

- The higher concentrations and severity of liquefaction effects to the east, in the area of the third subevent of the earthquake, suggest that groundmotion durations were longer in that area during the earthquake, resulting from a longer slip event.

\section{REFERENCES CITED}

Eberhart-Phillips, D., Haeussler, P.J., Freymueller, J.T. Frankel, A.D., Rubin, C.M., Craw, P., Ratchkovski, N.A Anderson, G., Carver, G.A., Crone, A.J., Dawson, T.E., Fletcher, H., Hansen, R., Harp, E.L., Harris, R.A., Hill, D.P., Hreinsdóttir, S., Jibson, R.W., Jones, L.M., Kayen, R., Keefer, D.K., Larsen, C.F., Moran, S.C., Personius, S.F., Plafker, G.,
Sherrod, B., Sieh, K., Sitar, N., and Wallace, W.K., 2003, The 2002 Denali Fault earthquake, Alaska: A large magnitude, slip-partitioned event: Science, p. 1113-1118.

Evans, S.G., and Clague, J.J., 1988, Catastrophic rock avalanches in glacial environments, in Bonnard, C., ed., Landslides-Glissements de terrains: Proceedings, 5th International Symposium of Landslides, Lausanne, v. 2 p. 1153-1159.

Frankel, A.D., Biswas, N.N., Martirosyan, A.H., Dutta, U., and McNamara, D.E., 2002, Rupture process of the M 7.9 Denali Fault, Alaska, earthquake determined from strongmotion recordings: Eos (Transactions, American Geophysical Union) '83 (47), Fall Meeting Supplement Abstract no. S72F-1340.

Harp, E.L., and Jibson, R.W., 1995, Inventory of landslides triggered by the 1994 Northridge, California, earthquake: U.S. Geological Survey Open-File Report 95-213, 18 p.

Keefer, D.K., 2002, Investigating landslides caused by earthquakes-A historical review: Surveys in Geophysics, v. 23, no. 6, p. 473-510

Keefer, D.K., 1993, The susceptibility of rock slopes to earthquake-induced failure: Bulletin of the Association of Engineering Geologists, v. XXX, no. 3, p. 353-361.

Keefer, D.K., 1984, Landslides caused by earthquakes: Geological Society of America Bulletin, v. 95, p. 406-421.

Kikuchi, M., and Yamanaka, Y., 2002, Source rupture processes of the central Alaska earthquake of Nov. 3, 2002, inferred from teleseismic body waves (the 10/23 M6.7 event), Earthquake Information Center Seismological Note, no. 129, http://wwweic.eri.u-tokyo.ac.jp/EIC/EIC_News/ 021103AL-e.html (November 4, 2002).

Miller, M.L., Bradley, D.C., Bundtzen, T.K., and McClelland, W., 2002, Late Cretaceous through Cenozoic strike-slip tectonics of southwestern Alaska: The Journal of Geology, v. 110 , p. $247-270$.

Plafker, G., Gilpin, L.M., and Lahr, J.C., 1994, Neotectonic map of Alaska, in Plafker, G., and Berg, H.C., eds., The geology of Alaska: Boulder, Colorado, Geological Society of America, Geology of North America, v. G-1, Plate 12.

Plafker, G., Hudson, T., and Richter, D.H., 1977, Preliminary observations on late Cenozoic displacements along the Totschunda and Denali Fault systems: U.S. Geological Survey Circular, v. 751-B, p. B67-B69.

Plafker, G., Ericksen, G.E., and Fernández Concha, J., 1971, Geological aspects of the May 31, 1970, Peru earthquake: Seismological Society of America Bulletin, v. 61, p. 543-578.

Seed, H.B., and Lee, K.L., 1966, Liquefaction of saturated sands during cyclic loading: Journal of the Soil Mechanics and Foundations Division, ASCE, v. 92, no. SM6, Paper 4972, November, p. 105-134.

Shaller, P.J., 1991, Analysis and implications of large Martian and terrestrial landslides [Ph.D. Dissertation]: Pasadena, California, California Institute of Technology, p. 586.

Tuthill, S.J., and Laird, W.M., 1966, Geomorphic effects of the earthquake of March 27, 1964, in the Martin-Bering Rivers area, Alaska: U.S. Geological Survey Professional Paper 543-B, p. 1-29.

Manuscript submitted February 20, 2003; accepted May 28, 2003. 